\title{
Writing the Deal: Statistical Analysis of Brazilian Business Negotiations on Intangible Assets
}

\author{
Murillo de Oliveira Dias, Raphael de Almeida Leitão, \\ Rodolfo Milhomem Batista, and Davi Monteiro de Medeiros
}

\section{ABSTRACT}

In times of coronavirus pandemic, and consequently, lockdowns, home office, social isolation, delta, and omicron variants, the development of writing negotiation skills are critical for success in business negotiations. These days, instant messaging and e-mail, two ubiquitous forms of electronic communication are used on a large scale, as an alternative to face-to-face negotiations. However, business asynchronous negotiations have their difficulty levels and pitfalls. This article addressed the challenges of asynchronous communication through the statistical analysis of $N=1,400$ Brazilian business negotiations on intangible assets. Key findings pointed out a strong, positive correlation between open and close value deals $(\rho=0.939$, $p<0.010)$. The linear regression analysis showed significant non-parametric residuals. Moreover, the average between open and close values is $\mathbf{1 1 . 4}$ percent. We found evidence that anchoring is significant in business asynchronous negotiation on intangible assets. The conclusions are limited to the data set under investigation. The article provides scholars, negotiators, and practitioners with a perspective on the writing negotiation through email or instant messaging.

Keywords: Business writing negotiations, intangible assets, anchoring effect.

\section{INTRODUCTION}

In the present article, we found statistical significance in Brazilian asynchronous business negotiations on intangible assets, involving $\mathrm{N}=2,800$ Brazilians from all five regions. Two parties received instructions to negotiate one issue in writing (acquisition price), via instant messaging, such as WhatsApp or Telegram, or Type I negotiation (Dias, 2020). The analysis suggested attention to challenges in business asynchronous negotiations such as (i) the anchoring effect, and how to (ii) structure business negotiations, to be addressed and further discussed in the following sections.

Business negotiations have attracted scholar attention in recent years (Dias, et al. 2015; Dias and Navarro, 2020, 2013; Dias and Lopes, 2020; Dias, M; Madureira, A; Lima, M; Mororó, C; Leite, A; Prates, W; Salvador, G; Araújo, H; Souza, A; Oliveira, M; Marques Filho, C., 2021; Dias and Lopes 2021; Dias, 2018; 2016); Dias, 2021, 2020, 2020b; 2019 , 2018), among others. This study was designed for addressing business negotiations on intangible assets through writing communication. Other negotiations, such as negotiations involving third parties (Type III negotiation), should be investigated in additional studies.

Salacuse (2003) defined Negotiation as a "process of communication by which two or more persons seek to advance their interests through joint action." (p. 7) Moreover, Fisher, Ury \& Patton (1981) reported negotiation as "a Fig. 1.
Submitted : December 29, 2021

Published : January 20, 2022

ISSN: $2507-1076$

DOI: $10.24018 /$ ejbmr.2022.7.1.1233

Dr Murillo de Oliveira Dias*

Fundação Getulio Vargas, Professor,

Brazil.

(e-mail: agenda.murillo@ gmail.com)

Raphael de Almeida Leitão

Air Force University, Master's Student of

the PPGCA-UNIFA, Brazil.

(e-mail: leitao_raphael@hotmail.com)

Rodolfo Milhomem Batista

Air Force University, Master's Student of

the PPGCA-UNIFA, Brazil.

(e-mail: rmilhomem@ gmail.com)

Davi Monteiro de Medeiros

Air Force University, Master's Student of the PPGCA-UNIFA, Brazil.

(e-mail: davidmm ${ }^{\circledR}$ decea.gov)

*Corresponding Author

process of communicating back and forth to reach a joint decision." (p. 20). Asynchronous, is negotiation with a time delay between offers, through instant messaging or e-mail . In addition, according to Dias (2020), a negotiation can be categorized into four types: (i) Type I, two-parties, one issue; (ii) Type II, two-parties; multiple issues; (iii) Type III, multiple-parties, one issue - negotiation, and (iv) Type IV, multiple parties, multiple issues - negotiation, as depicted in

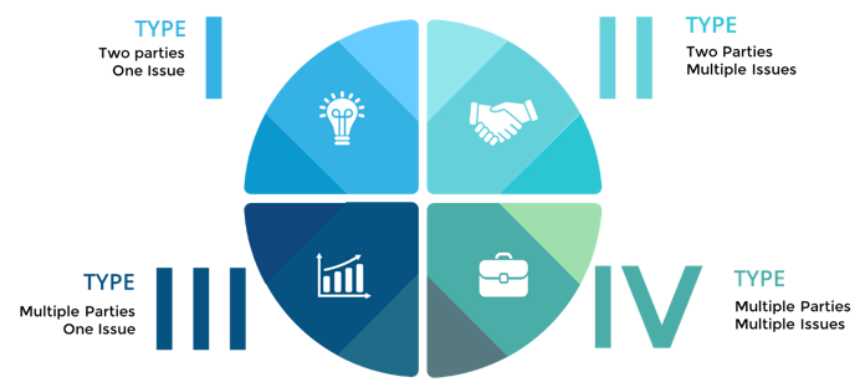

Fig. 1. The Four-Type Negotiation Matrix. Source: Dias, 2020. Reprinted under permission.

Observe in Fig. 1 that the investigation is limited to Type I negotiation. Finally, intangible assets negotiation involve "variations of intellectual, structural, and relationship capital, emotional attachment to a tangible asset under Negotiation, such as an internet Uniform Resource Locator (URL), for 
instance." (Dias, 2020b, p.1,421). Moreover, two variables were investigated in the present research: (i) independent variable: open (OPEN) and (ii) dependent variable close (CLOSE) value deals.

In the present study, the following assumptions were considered, regarding the data set investigated: (i) the open value somehow influences the close value; (ii) an intangible asset is more difficult to be valued than a tangible asset. Therefore, OPEN is not a predictor for CLOSE; (iii) the samples (deals) are independent, i.e., the outcome of a given negotiation does not interfere with another negotiation. The negotiations were conducted separately with no mutual interference; (iv) the confidence interval is 99 percent.

Moreover, three research questions were addressed in this investigation, as follows: (i) is there statistical significance between OPEN and CLOSE values? (ii) Is it possible to predict a close value (dependent variable) from an initial value in mainly intangible assets business negotiation cases? Finally, (iii) does the anchoring effect influence the results? Finally, this article compiles the following sections: (i) Hypothesis; (ii) research methods and design: (iii) results and analysis; (iv) implications and research limitations, and (v) conclusion. In the next section, the research hypotheses are resented.

\section{HYPOTHESIS}

$\mathbf{H}_{\mathbf{0}}$ : The close value (dependent variable) is not affected by the open value (independent variable) in the intangible assets business negotiations from the data set. In sum, the close value is not affected somehow by the open value.

Therefore, $\mathbf{H}_{0}=\mu \mathrm{OPEN}=\mu \mathrm{CLOSE}$, or $\mathrm{H}_{0}=\mu \mathrm{OPEN}$ $\mu \mathrm{CLOSE}=0$, where: $\mu \mathrm{OPEN}$ is the mean opening value, and $\mu \mathrm{CLOSE}$ is the mean close deal value.

$\mathbf{H}_{\mathbf{a}}$ : The negotiation close value correlates to open value in the intangible assets business negotiations. In sum, there is a significant correlation between open and close values in the negotiations analyzed.

\section{Methods AND RESEARCH DESIGN}

The present research follows a positivistic approach and deductive rationale. A series of statistical tests were applied to $\mathrm{N}=1,400$ deals. The confidence interval adopted for this research is 99 percent $(\mathrm{p}<0.010)$. A Type I role-play simulation was applied to 2,800 Brazilian business negotiators, from all five Brazilian regions. The sample $(\mathrm{N}=1,400)$ was randomly chosen from a data set of 8,000 deals, collected over the past decade of business negotiations. In total, 60 cohorts were investigated from January 2012 to December 2021. In total, $\mathrm{N}=1,400$ intangible asset business negotiations cases were assigned to 2,800 participants. Every two participants received the same set of instructions. IBM SPSS 26 (Brazilian Portuguese version) was employed to analyze data. Regarding the ethnographic data, out of the 2,800 research subjects, 65 percent were male, 35 percent female, 72 percent in the middle to high-level management positions, and 30 percent occupied low-level management positions; 85 percent are employed, from which 80 percent Caucasians, 60 percent married, 40 percent single, divorced, or other; 62 percent were 25-35 years old, 23 percent above 35 years old. The negotiators had at least three years of business negotiation experience. All the participants are MBA students, taking day and night negotiation sessions, within and outside business hours.

The participants were told to read the instructions and to engage in the negotiation via instant messaging. After the negotiation was concluded, the participants should report (i) deal or no deal; (ii) the open value, and (iii) the close value. Finally, raw data was input into SPSS and further analyzed. The first test conducted was the normality test. Next, correlation and linear regression tests were applied to the data. The equations for the Shapiro-Wilk test is as follows:

$$
W=\frac{\left\{\sum_{i=1}^{n} a_{i}\left(x_{(n-i+1): n}-x_{i: n}\right)\right\}^{2}}{\sum_{i=1}^{n}\left(x_{i}-\bar{x}\right)_{2}}
$$

The linear regression analysis equation is as follows:

$$
Y=\beta 0+\beta 1 . X i+\varepsilon
$$

\section{RESUlTS AND ANALYSIS}

Table I illustrates the results of the Shapiro-Wilk normality test, due to the number of samples investigated $(\mathrm{N}>100)$ :

TABLE I: NORMALITY TESTS

\begin{tabular}{ccccccc}
\hline \multicolumn{7}{c}{ Normality Tests } \\
\hline Statistics & \multirow{7}{c}{ gl } & & & \multicolumn{3}{c}{ Shapiro-Wilk } \\
0,179 & 1400 & & Sig. & Statistics & gl & Sig. \\
CLOSE & & & 0,000 & 0,787 & 1400 & 0,000 \\
\hline
\end{tabular}

a. Correlação de Significância de Lilliefors.

Source: SPSS 26.

Notice in Table I that $\mathrm{p}<0.010$ for both variables, resulting in non-parametric variables, i.e., the distribution of the results did not follow a normal distribution, as the dependent variable (CLOSE) depicted in the histogram illustrated in Fig. 2.

The Shapiro-Wilk test revealed that the Pearson correlation test was not suitable to analyze the data. Therefore, a Spearman correlation test was conducted, as is depicted in Table II:

TABLE II: SPEARMAN CORRELATION TEST

\begin{tabular}{ccccc}
\hline \multicolumn{4}{c}{ Correlations } \\
\hline & & OPEN & CLOSE \\
\hline \multirow{4}{*}{$\rho$} & Correlation Coefficient & 1,000 & $0,939^{* *}$ \\
Spearman & Sig. (1 end) &. & 0,000 \\
& & $\mathrm{~N}$ & 1400 & 1400 \\
& & Correlation Coefficient & $0,939^{* *}$ & 1,000 \\
& CLOSE & Sig. (1 end) & 0,000 &. \\
& & $\mathrm{~N}$ & 1400 & 1400 \\
\hline
\end{tabular}

**.The correlation is significant at level 0.01 (1 extremity). Source: SPSS 26

Observe in Table II the Spearman correlation between OPEN and CLOSE variables. Also, that $\mathrm{R}^{2}=0.88$. Next, a scatter plot is shown in Fig. 3 . 


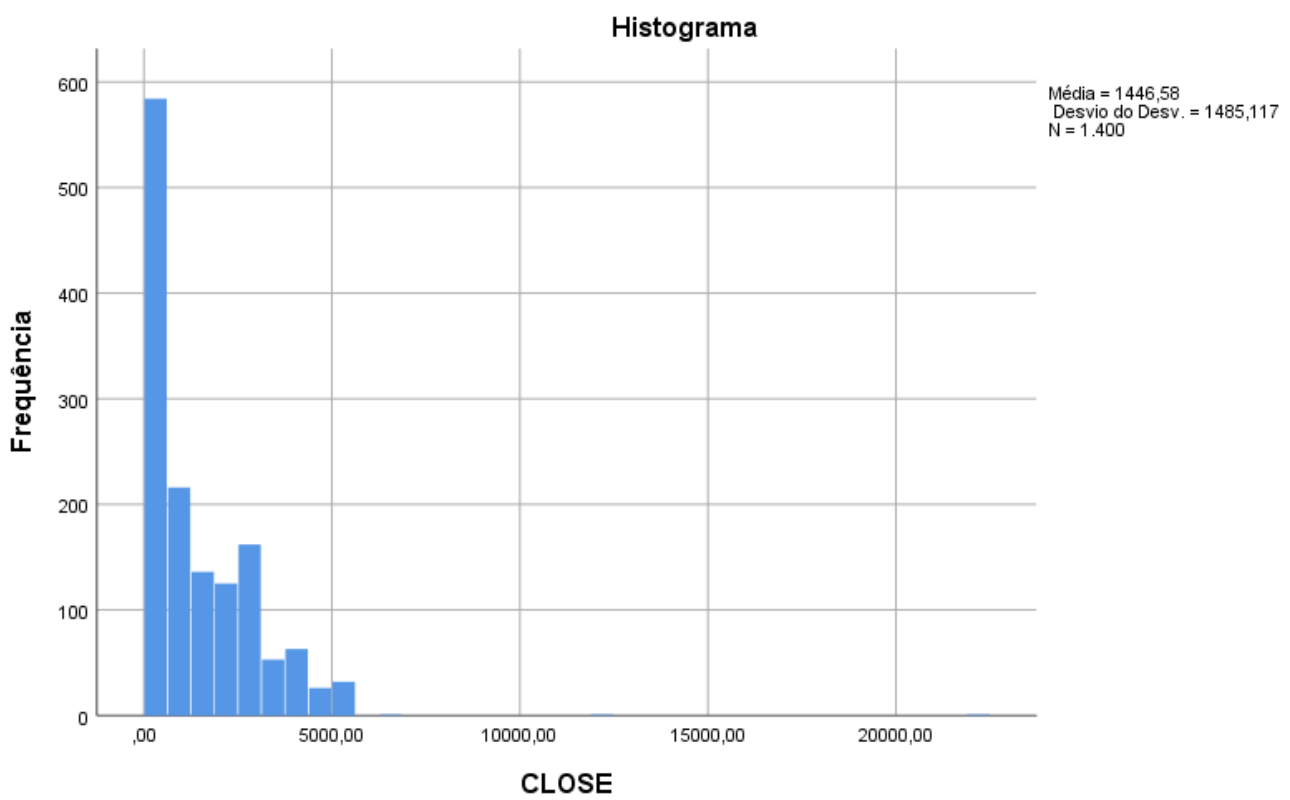

Fig. 2. Close values frequency. Source: SPSS 26.

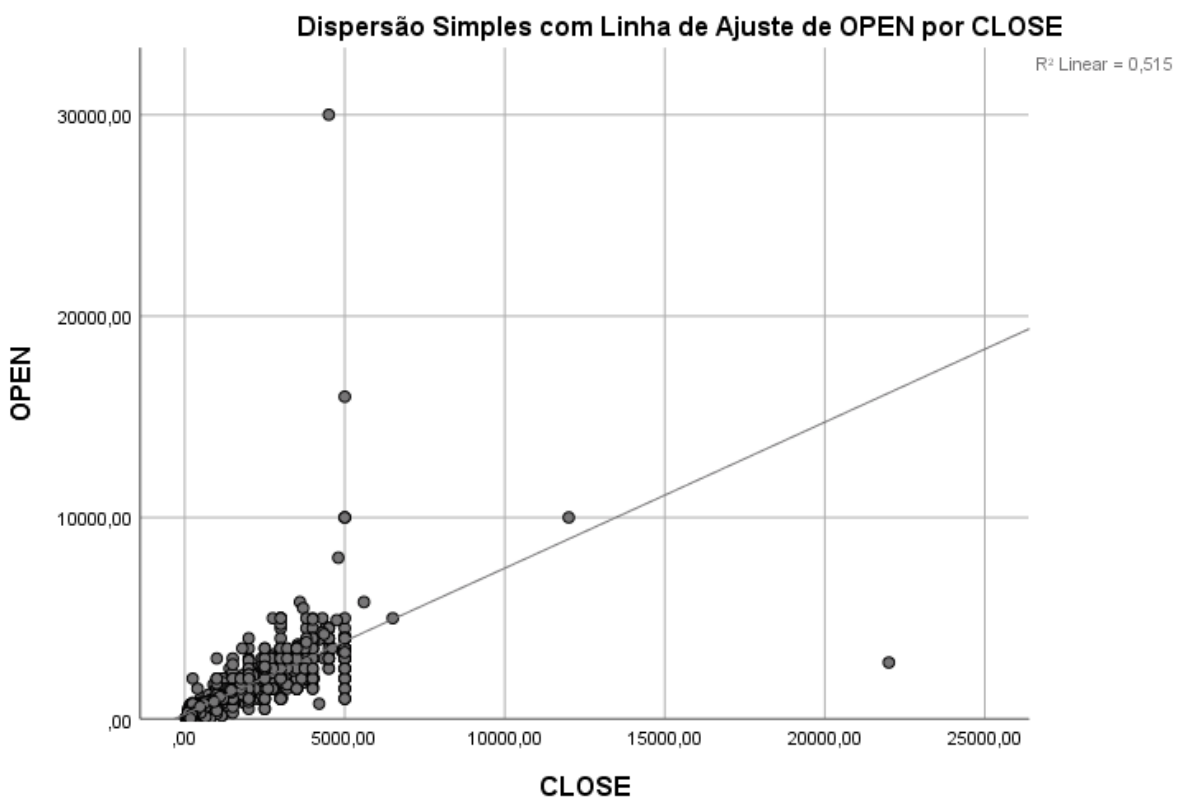

Fig. 3. Scatter plot. Source: SPSS 26.

Notice in Fig. 3 the data dispersion, diagonally distributed. coefficients test, depicted in Tables IV and V:

The Spearman correlation showed a strong, positive correlation between OPEN and CLOSE variables ( $\rho=0.939$; $\mathrm{p}<0.10$ ), i.e., if the OPEN value increases, the CLOSE increases too, and the variables are strongly connected. Furthermore, $\mathrm{p}<0.10$ also indicates that the null hypothesis is rejected, as illustrated in Table III, as follows:

TABLE III: HYPOTHESIS TEST

\begin{tabular}{cccc}
\hline \multicolumn{4}{c}{ Hypothesis test report } \\
\hline Null hypothesis & Test & Sig. & Decision \\
\hline $\begin{array}{c}\text { The distribution } \\
\text { between OPEN } \\
\text { and CLOSE is } \\
\text { equal to 0. }\end{array}$ & $\begin{array}{c}\text { Related Samples of } \\
\text { Wilcoxon Signed } \\
\text { Rank Test }\end{array}$ & 0,000 & $\begin{array}{c}\text { Reject the } \\
\text { Null } \\
\text { hypothesis. }\end{array}$ \\
\hline
\end{tabular}

Asymptotic significance is displayed. The significance level is, 010 . Source: SPSS 26.

The linear regression test determined if there would be a predictive relationship between the dependent and independent variables resulting in the ANOVA, and

\begin{tabular}{lcccccc}
\multicolumn{8}{c}{ TABLE IV:ANOVA } \\
\hline \multicolumn{7}{c}{ ANOVA $^{\mathrm{a}}$} \\
\hline Model & Sum of & Df & Middle Square & Z & Sig. \\
& & Squares & & & & \\
\hline 1 & Regression & 1590496158,807 & 1 & 1590496158,807 & 1487,202 & $0,000^{\mathrm{b}}$ \\
& Residue & 1495098815,429 & 1398 & 1069455,519 & & \\
& Total & 3085594974,236 & 1399 & & & \\
\hline
\end{tabular}

a. Dependent Variable: CLOSE
b. Predictors: (Constant), OPEN

Source: SPSS 26.

\begin{tabular}{|c|c|c|c|c|c|c|}
\hline \multicolumn{7}{|c|}{ Coefficients $^{\mathrm{a}}$} \\
\hline \multirow{2}{*}{\multicolumn{2}{|c|}{ Model }} & \multicolumn{2}{|c|}{$\begin{array}{c}\text { Non standardized } \\
\text { coefficients }\end{array}$} & \multirow{2}{*}{$\begin{array}{c}\begin{array}{c}\text { standardized } \\
\text { coefficients }\end{array} \\
\text { Beta } \\
\end{array}$} & \multirow[t]{2}{*}{$\mathrm{t}$} & \multirow[t]{2}{*}{ Sig. } \\
\hline & & $\mathrm{B}$ & Error & & & \\
\hline \multirow[t]{2}{*}{1} & $\begin{array}{c}\text { (Consta } \\
n t)\end{array}$ & 535,764 & 36,355 & & 14,737 & 0,000 \\
\hline & OPEN & 0,711 & 0,018 & 0,718 & 38,564 & 0,000 \\
\hline
\end{tabular}

a. Dependent variable: CLOSE.

Source: SPSS 26. 
However, regarding the investigation of the residuals statistic for the sample investigated, Table VI depicts the interval between residual errors is more significant than -3 to +3 . be investigated in additional studies or in separate. Other countries or scenarios may differ in results. The conclusions are, thus, limited to the dataset investigated $(\mathrm{N}=1,400$ negotiations).

TABLE VI: RESIDUAL STATISTICS

\begin{tabular}{|c|c|c|c|c|c|}
\hline \multicolumn{6}{|c|}{ Residuals Statistic $^{a}$} \\
\hline & Min & Max & Average & Std Dev & $\mathrm{N}$ \\
\hline $\begin{array}{l}\text { Anticipated } \\
\text { value }\end{array}$ & 548,5568 & 21857,0781 & 1446,5811 & 1066,24610 & 1400 \\
\hline $\begin{array}{l}\text { Residue } \\
\text { Error }\end{array}$ & $-17357,07812$ & 19474,24609 & 0,00000 & 1033,77516 & 1400 \\
\hline $\begin{array}{l}\text { Anticipated } \\
\text { value }\end{array}$ & $-0,842$ & 19,142 & 0,000 & 1,000 & 1400 \\
\hline Error Residue & $-16,784$ & 18,831 & 0,000 & 1,000 & 1400 \\
\hline
\end{tabular}

a. Variável Dependente: CLOSE.

Source: SPSS 26.

Therefore, the residuals are not normally distributed, and there is no causal relationship between CLOSE and OPEN variables in the data set studied.

However, despite the absence of a causal relationship between variables, i.e., a given open value does not predict a close amount in this sample, the comparison of the mean revealed an interesting result, displayed in Table VII:

TABLE VII: MEANS COMPARISON

\begin{tabular}{|c|c|c|c|}
\hline \multicolumn{4}{|c|}{ Report } \\
\hline \multicolumn{2}{|c|}{ GROUP } & CLOSE & OPEN \\
\hline HUNDREDS & Mean & 405,6678 & 372,7282 \\
\hline THOUSANDS & $\mathrm{N}$ & 694 & 694 \\
\hline \multirow[t]{5}{*}{ Total } & Std Error & 474,84720 & 362,45922 \\
\hline & Mean & 36,00 & 18,00 \\
\hline & $\mathrm{N}$ & 4500,00 & 3500,00 \\
\hline & Std Error & 4464,00 & 3482,00 \\
\hline & Mean & $49,6 \%$ & $49,6 \%$ \\
\hline HUNDREDS & $\mathrm{N}$ & 2469,8018 & 2174,9414 \\
\hline \multirow[t]{6}{*}{ THOUSANDS } & Std Error & 706 & 706 \\
\hline & Mean & 1428,29545 & 1650,73155 \\
\hline & $\mathrm{N}$ & 150,00 & 100,00 \\
\hline & Std Error & 22000,00 & 30000,00 \\
\hline & Mean & 21850,00 & 29900,00 \\
\hline & $\mathrm{N}$ & $50,4 \%$ & $50,4 \%$ \\
\hline Total & Std Error & 1446,5811 & 1281,5585 \\
\hline \multirow[t]{6}{*}{ HUNDREDS } & Mean & 1400 & 1400 \\
\hline & $\mathrm{N}$ & 1485,11677 & 1500,25389 \\
\hline & Std Error & 36,00 & 18,00 \\
\hline & Mean & 22000,00 & 30000,00 \\
\hline & $\mathrm{N}$ & 21964,00 & 29982,00 \\
\hline & Std Error & $100,0 \%$ & $100,0 \%$ \\
\hline
\end{tabular}

Source: SPSS 26.

Observe in Table VII that the results were arranged in two distinct groups, according to the open and value deals for each negotiation: (i) HUNDREDS, and (ii) THOUSANDS, of BRL.

\section{IMPLICATIONS AND RESEARCH LIMITATIONS}

The conclusions have implications in several fields of study: (i) contract negotiations (Cunha, Dias, 2021); (ii) Civil Engineering Works Negotiation Dias, M.; Bezerra, A, Sousa, J.C., Costa, H.; Schmitz, F., Santos, C; Moreira, A.; Mattos, S.; Neves, M.; Filho, N.; Filho, C.C., 2021); (iii) Credit cooperative negotiations (Dias and Teles, 2018); (iv) intangible assets negotiation (Dias, 2020b), among others. wThe study was designed to address asynchronous Brazilian business negotiations on intangible assets (Type I negotiation). In other countries, types of negotiation should

\section{CONCLUSION}

In this section, the answers to the research questions are presented and discussed, as follows:

(i) Is there any causal relationship between OPEN and 1400 CLOSE values? The answer is yes. The analysis of the results of the Spearman Correlation test indicated a positive, strong correlation between OPEN and CLOSE variables $(\rho=0,939$, $\mathrm{p}<0.10)$. Additionally, the null hypothesis is rejected. Therefore, the open value does influence somehow the close value, as illustrated in Table I.

(ii) Is it possible to predict a close value (dependent variable) from an initial value in mainly intangible assets business negotiation cases? The answer is no. The residuals (outliers) are not normally distributed in this sample, explained by the number of atypical negotiation results, as depicted in Figure 10.

(iii) Does the anchoring effect influence the results? The answer is yes. According to Ariely (2008), Bazerman and Moore (2009), Kahneman and Tversky (1982), the decisionmaking process is affected by the desire to win and loss aversion, affecting somehow the initial offer or bid, in the negotiations described.

In conclusion, the initial offer (OPEN) exerts an attraction to the close deal (CLOSE). Note in Figure 11 in the HUNDREDS group, that OPEN is 8.11 percent distant from CLOSE values. In the THOUSANDS group, OPEN is 11.2 percent distant from CLOSE values. On average, OPEN is 11.4 percent distant from CLOSE values. In the next sections, the implications and research limitations are disclosed. In sum, we found statistical relevance between OPEN and CLOSE values that cannot be attributed to chance $(\mathrm{p}<0.010)$.

Finally, the OPEN and CLOSE values (BRL), i.e., the price of the intangible asset, answers for 88.17 percent of the phenomenon under investigation $\left(\mathrm{R}^{2}=0.8817\right)$. Therefore, the asset price negotiations proved to be crucial for the dataset investigated.

\section{FUTURE RESEARCH}

This study investigated Brazilian business negotiations on intangible assets. For future research, we encourage the qualitative investigation on the participants to address the rationale behind their price choices, as well as the reasons to be the first bidder. We also encourage the investigation of other Types of negotiation (Dias, 2020), such as Type II, III, and IV (see Fig. 1). The investigation of business asynchronous negotiations in other countries is finally recommended.

\section{CONFLICT OF INTEREST}

The authors declare that they do not have any conflict of interest. 


\section{REFERENCES}

Ariely, Dan (2008). Predictably Irrational. USA: Harper Collins.

Bazerman, Max; Moore, Don A. (2009) Judgment in Managerial Decision Making. USA: John Wiley and Sons Inc., 7th edition.

Cunha, N.C., Dias, M. (2021) Contract Negotiation: When the Detail Saved the Day.GSJ 9(12), 130-141; doi: 10.11216/gsj.2021.12.56418.

Dias, M. (2020) The Four-Type Negotiation Matrix: A Model for Assessing Negotiation Processes. British Journal of Education, 8(5), 40-57. doi: 10.6084/m9.figshare.12389627.

Dias, M. (2020b) Predictive Model on Intangible Assets Negotiation: Linear Regression Analysis. Journal of Xidian University, 14(7), 1420-1433. doi: 10.37896/jxu14.7/161

Dias, M. (2020b) Structured versus Situational Business Negotiation Approaches. Journal of Xidian University, 14(6), 1591 - 1604. doi: 10.37896/jxu14.6/192.

Dias, M. et al. (2014). Dudalina S/A: Case Study on How to Overcome Succession Barriers on a Brazilian Family Business. Business and Management Review, 3(12), 217-229. doi: 10.6084/m9.figshare.7834748.

Dias, M. et al. (2015). Brazilian Fashion Business Dudalina S/A: Case Revisited. International Journal of Business and Management Studies, 4(1), 11-24. doi: 10.6084/m9.figshare.7834730.

Dias, M., Lopes, R., Cavalcanti, G., Golfetto, V. (2020) Role-Play Simulation on Software Contract Negotiation. Global Scientific Journals, 8(6), 1-10. doi: 10.11216/gsj.2020.06.40176.

Dias, M., Lopes, R., Duzert, Y. (2020) Mapping the Game: Situational versus Structured Negotiations. Saudi Journal of Economics and Finance, 4(6): 271-275. doi: 10.36348/sjef.2020.v04i06.012.

Dias, M.; Davila Jr., E. (2018) Overcoming Succession Conflicts in a Limestone Family Business In Brazil. International Journal of Business and Management Review, 6(7), 58-73. doi: $10.6084 / \mathrm{m} 9$.figshare.7834703.

Dias, M.; Duzert, Y. (2017). Teaching Materials: Role Play Simulation on EBusiness Negotiation. European Journal of Training and Development Studies, 4(3), 1-15. doi: 10.6084/m9.figshare.7834655.

Dias, M.; Ramos, M. (2018). Credit Cooperatives in Brazil. International Journal of Science and Research (IJSR), 7(10), 598-603. doi: 10.21275/ART20191901.

Dias, M.; Silva, Cleber A.; Lund, Myrian (2019) Brazilian Credit Cooperatives: Cresol Confederation Case. IOSR Journal of Busines and Management, 21(5), 11-19. doi: 10.9790/487X-2105051119.

Dias, M.; Teles, Andre (2018). Agriculture Cooperatives in Brazil and the Importance for The Economic Development. International Journal of Business Research and Management, 9(2), 72-81. doi: 10.6084/m9.figshare.7832354.

Dias, M.; Teles, Andre (2019). A Comprehensive Overview of Brazilian Legislation on Credit Cooperatives. Global Journal of Politics and Law Research, 7(4), 1-12. doi: 10.13140/RG.2.2.25054.28488.

Fisher, R. Ury, W. \& Patton, B (Editor). (1981). Getting to Yes: Negotiating an Agreement without Giving in. US: Random House.

Kahneman, Daniel; Slovic, Paul; Tversky, Amos. (1982). Judgment under Uncertainty: Heuristics and Biases. New York: Cambridge University Press.

Salacuse, J. (2008). Seven Secrets for Negotiating with Government: How to Deal with Local, State, National, Or Foreign Governments - And Come Out Ahead. New York: Amacom.

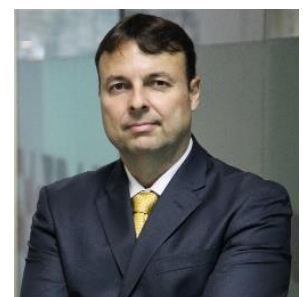

Prof. Dr. Murillo Dias holds a Doctorate in Business Administration from Rennes School of Business, France. Master's degree in Administration held from FGV/EBAPE. MBA in Business Management from FGV-RJ graduated in Electronic Engineering from CEFET-RJ. Holds the international certifications: PMP, MBTI I and II, and Thomas DISC. Professional experience of more than 25 years as a manager and entrepreneur. FGV Guest professor and coordinator of management courses. Consultant/trainer to the following companies: White Martins, SICOOB, Semp Toshiba, Grupo Brasif, Sharp, Ricoh, Penn Foster, Gol Grupo, ESSEC (France, FGV DINT, Duas Rodas, Machado Meyer, Mitsui, AASP, FIAT, IFA (Investment Agency in France, Ogilvy, Eletrobrás, Furnas, Embraer, White Martins, Chemtech- Siemens, Radix, Engenharia SICREDI, CRESOL, SESCOOP, UNIMED, AURORA Alimentos, Petrobrás, among others. Author of +120 articles published in 21 countries, as well as courses and books. It received a total of 18 awards - highlighting the AC4 award, granted by Columbia University (USA). Member of the editorial boards: London Journal Press (United Kingdom); Journal of Research and
Literature (USA); Institute of Scholars and Deccan Business Review (India). Member of the International Association for Conflict Management-IACM (USA) 